\title{
AN ANTIMONOPOLY POLICY FOR NORTH AMERICA: OPPORTUNITIES AND PROBLEMS
}

\author{
JAMES W. MCKIE*
}

I

Economic Integration And Antimonopoly POLICY

\section{A. Free Trade and Competition}

Economic integration, common markets, and customs unions can have different objectives. Some of these institutions are predominantly "trade-diverting", to use Jacob Viner's phrase; they create a closed association for the protection of higher-cost suppliers within their boundaries at the expense of lower-cost suppliers outside. Others are predominantly "trade-creating;" they generate new sources of low-cost supply within the union by enlarging the market for each of the component countries. ${ }^{1}$ One cannot say a priori which effect would predominate in North American economic integration.

This paper assumes that advocates of North American economic union expect it to create more effective competition. Under this theory, enlargement of the market makes new alternatives available to consumers and to buyers of intermediate products and raw materials. Economic integration opens new markets to existing suppliers, and makes entry more inviting. It removes the protection of tariffs and quotas from favored producers, and forces them to meet the standards of efficiency that low-cost producers elsewhere in the union can achieve. It enables firms in small countries to attain optimum economies of scale and integration when previous national markets were too small. It may convert monopoly into oligopoly, oligopoly into imperfect competition, dominant firm collusion into open rivalry, and so on. ${ }^{2}$

These effects on competition flow in the first instance from the changes in trade policy that economic integration usually requires: abolition of tariffs, elimination of import and export quotas, eradication of discrimination against other members

\footnotetext{
Copyright 1981 by Law and Contemporary Problems.

*Professor of Economics, The University of Texas at Austin. The author wishes to acknowledge the helpful criticisms and suggestions of Professors William P. Glade, Jr., Wendell Gordon, Stanley Ross, and Sidney Weintraub, and the kind assistance of the Consulate of Canada, Dallas, in obtaining copies of governmental reports. None of these people are responsible in any way for any of the substantive statements in the paper. Remaining defects are the sole responsibility of the author.

1. J. Viner, The Customs Union Issue 41-46 (1961). See also D. McLachlan \& D. Swann, ComPETITION POLICY IN THE EuRopean COMmunity, chs. 1, 5 (1967).

2. D. MCLAChLAN \& D. SWANN, supra note 1 .
} 
of the union, and abandonment of subsidies. If the agreement went only as far as customs union, trade policy would be the only source of improvement in competition.

In a closer form of integration, however, a common antitrust policy can supplement trade policy in furthering effective competition. If total integration were contemplated, full economic and political union under a single sovereignty, a single and uniform antitrust policy would prevail. That is not, of course, a realistic expectation in the case of North America. In a common market or other limited economic union, a common antitrust policy would have to be reconciled with the remaining policies of the countries forming the union. Some problems may arise in the formulation and application of a common policy on competition, and these problems may demonstrate some obstacles to the initial formation of the union.

One must assume some structure among the many possible forms and degrees of economic union among the countries of North America. Though some segments of public opinion in both Canada and Mexico are vehemently opposed to North American economic integration, ${ }^{3}$ this paper will assume that a proposal is before us to combine those two countries and the United States into a North American Economic Community (NAEC) that would include the following elements:

(1) It would constitute a free-trade area within itself, and would work toward the goal of a common external tariff-a customs union.

(2) It would have a political arm that would enable the Community to enforce an "antitrust" policy throughout the territory of its members, subject to exceptions and negotiated preferences.

(3) It would permit the movement of persons across national frontiers in search of employment, subject to certain restrictions imposed by the several member states.

(4) It would permit flow of investment across national frontiers, subject again to certain restrictions (such as those on foreign corporation affiliates) imposed by the several member states. Some industries might by agreement be closed to foreign investment.

This paper will concentrate on the second element, a common antitrust or antimonopoly policy, rather than on details of trade policy, though the two are necessarily related. The assumed restrictions on movement of persons and investment are meant merely as realistic provisos. The relation of restrictions of foreign investment to a Community antitrust policy will be clarified below. The European Economic Community (EEC) does not have equivalent restrictions on factor movements, but the EEC policy on monopoly and competition may help to indicate the possibilities for a NAEC.

\section{B. The European Economic Community as a "Model"}

The Treaty of Rome, the constitution of the EEC, included explicit provisions for antitrust policy and enforcement.

3. E.g., the "Remarks" by Dr. Mark MacGuigan, Secretary of State for External Affairs of Canada, to the Cincinnati Council on World Affairs, October 17, 1980: "[I]t should not come as a surprise that we are unreceptive to schemes for continental economic integration which some would superimpose on the established pattern of bilateral links." (News-Canada, Press Release 61/80, p. 5) "Bilateral links" are a rudimentary form of economic union themselves, but they usually impinge on antitrust policy only by creating exceptions. See also the joint Mexican-Canadian statement of May 27, 1980, rejecting trilateral North American economic integration. NEW YORK TIMEs, May 28, 1980, at D-5. 
Article 85 prohibits any agreement between or association of enterprises and any concerted practices which are likely to affect trade between Member States and which have as their object or result the prevention, restriction or distortion of competition within the Common Market. ${ }^{4}$ The following practices are among those singled out:
(a) Direct or indirect fixing of purchase or selling prices or other terms of sale.
(b) Limitation or control of markets, production, investment or technology.
(c) Sharing of markets or sources of supply.
(d) Price discrimination injurious to trading parties.
(e) Tying arrangements that actually restrict competition.

Agreements that improve production or distribution or technical progress without eliminating competitors (i.e., commodity agreements among Member States) may be exempt. ${ }^{5}$ All agreements must be registered with the EEC Commission. ${ }^{6}$

Article 86 prohibits "action by one or more enterprises to take improper advantage of a dominant position within the Common Market," including, the abovementioned practices. ${ }^{7}$

The staff of the Commission of the EEC may bring complaints, as may any Member State. The Commission may request offenders to cease offensive practices; if they do not, the matter can be referred to the Court of Justice which may issue mandatory orders and impose fines for violations. It is understood that the law of the EEC on restrictive trade practices will take precedence over the laws of the individual Member States when a practice or agreement involves or affects the economies of other Member States. ${ }^{8}$

The Commission has actually intervened in the affairs of certain Member States to negotiate elimination of state-sponsored monopolies. It has opened the market for cigarettes in France and salt and tobacco in Italy, formerly government monopolies, to competitive suppliers elsewhere in the Community. ${ }^{9}$

On the other side of the balance, however, is the virtual exclusion of agriculture from the competitive policy of the Community.

The EEC incorporates the preexisting European Coal and Steel Community (ECSC), although the ECSC retains its own charter. The ECSC charter includes similar provisions on monopoly policy, and an even stronger clause requiring the consent of the Commission to mergers of firms in those industries. (It restrains the creation of dominant positions as well as their abuse.) The charter also permits control of prices and production in times of "manifest crisis" in steel or coal," which have come along rather frequently. Its cartel powers do not seem to work very well, since frequent disputes arise over state subsidies, the allocation of production quotas, etc. ${ }^{11}$ But in the opinion of most observers, ${ }^{12}$ the Coal and Steel

4. Excerpted and paraphrased from the text of the Treaty of Rome in A. CAMPBELL \& D. THOMPSON, Common Market LAW: Texts And Commentaries 246-48(1962).

5. Id.

6. $I d$.

7. Id.

8. Id.

9. A. Kerr, The Common Market and How It WORks 73 (1977) [hereinafter cited as KerR].

10. See, e.g., id. at 101-07.

11. Id.

12. Id. 
Community is substantially more competitive and more efficient than the national cartels and state-sponsored monopolies that would doubtless exist in its place. The ECSC, like the EEC's agricultural policy, affords an example of the compelling need to grant exceptions to certain activities within a competitive policy for a common market.

The Commission reports active enforcement of competition policy. In 1977 it made 17 decisions applying Articles 85 and 86, plus 20 more applying to the ECSC, and settled 263 cases by negotiation. It proceeded against market-sharing and price-fixing agreements. For example, it condemned and fined the members of an international trade association of vegetable parchment manufacturers for reservation of the British market, exchange of information on prices and quantities, and joint fixing of export prices. The Commission fined a Belgian automobile firm and certain of its distributors for banning exports. It authorized several steel industries' mergers under its specific ECSC merger control powers. It found that a Dutch petroleum company had abused its dominant position by discriminating against a customer in allocating supplies. And it secured the acquiescence of the French Government to the termination of the governmental alcohol monopoly in France. ${ }^{13}$

\section{The Focus of Policies to Promote Competition in a North American Economic Community}

If a North American Economic Community (NAEC) adopted a policy of enforcing rules of competition, that policy would presumably deal only with transnational problems. Purely internal ones (if indeed there are any in the interdependent world economy) would be left to the individual antitrust policies of the three countries. On the international level, the policy would have three main targets:

1. Cartels and other loose-knit agreements among firms in two or more of the North American countries. Some of these agreements would also involve firms in other countries outside the NAEC. If cartel agreements to fix prices, control production, or allocate markets are to be prohibited, the three countries must have a common policy regulating or prohibiting adherence by their firms to external cartels as well. While the attitudes of the three countries on this matter are not uniform, each government has favored industries and trades that it wants to protect or rationalize, often through compulsory cartellization. ${ }^{14}$ Each would retain the right to enter into international commodity agreements for certain goods, and these cartellike arrangements would be virtually immune from common-market competitive policy.

2. Unilateral monopoloid effects of trade. Such effects exist when a dominant firm or monopolistic organization in one country has monopoly power over a particular good in North America which is not effectively checked by competitive sources outside the region, or when it is able to gain a large share of the market in an

13. EEC, Eleventh General Report on the Activities of the European Communities in 1977104 (1978).

14. See examples in text below. 
importing country through predatory or discriminatory practices that eliminate local sources of supply and/or other imports. Rules of trade policy can deal with some of these effects, but in a NAEC the antitrust authority might have to take on most of the task of limiting a firm's exploitation of a dominant position in exporting goods to another NAEC country. Here again the Community might run against the obstacle of government-controlled enterprise. Could it, for instance, prevent the government-owned oil monopoly in Mexico from charging monopolistic prices for oil in the United States? Or from discriminating in favor of Mexican consumers?

3. Multinational corporations. The various fields of operation of multinational corporations (MNCs) present different problems to a common market. Some MNCs produce minerals and raw materials in some countries and export them to others-in North America, chiefly from Canada and Mexico to the United States. Most of these, but not all, are based in the United States and controlled by U.S. investors. Other MNCs have trading subsidiaries in one country that distribute goods, usually manufactured goods, exported from another-chiefly from the United States to Mexico and Canada, and on a much smaller scale from Canada to the United States and Mexico. Still others are manufacturing and service affiliates of MNCs whose home base is usually in the United States. Affiliates may license technology or trademarks from the "parent" firm under restrictive conditions that tend to limit development or use or restrain exports from the other country. In addition, of course, there are MNCs of all these types based in Europe or Japan with affiliates in all three North American countries; these would have to abide by any new rules of competition in a NAEC.

It was pointed out above that free (or mostly free) trade is itself a generator of competition. Its effects may be more powerful than any antitrust policy which might play only an auxiliary role in guaranteeing competition. The receptiveness of the individual countries of North America both to freer trade and to a commmunity antimonopoly policy, and the provisos, forms, and exceptions that each country would insist upon, would be strongly affected by the asymmetries among the three economies. These are much greater than the differences among the European economies of the EEC. Attitudes and policies toward monopoly and cartellization within each country would also affect the outcome, as would each country's perception of where monopoly problems are likely to originate. Weaker economies of developing countries are likely to take a protectionist stance toward domestic cartel arrangements. If the existing large firms within an economy are controlled by foreign interests, that country may not be eager to remove restraints on their expansion. It may not be receptive at all to the prospect of opening up domestic industry and trade to unimpeded access by foreign MNCs which may transform the economy to a more concentrated structure, at least in critical areas. In North America, the question of foreign control is intermingled with that of monopoly. A primary focus of an antimonopoly policy for the NAEC would be on the multinational corporation. Indeed, effective supervision of the MNC seems to be a leading problem for international economic policy, especially from the view- 
point of the developing countries. ${ }^{15}$

\section{II}

\section{A View of Mexico's Position}

\section{A. Mexican Attitude Toward Market Competition}

Mexican policy toward competition and market structure includes formal statements in the law relating to both the domestic economic structure and foreign ownership and control. The Mexican Constitution of 1917 guarantees freedom of commerce and industry to both Mexicans and foreigners, subject to certain restrictions (permitted by Article 27) on acquisition of property by foreigners, and on certain corporate activities. ${ }^{16}$ Article 28, the key provision in the Constitution relating to industrial structure, states, "There shall be no monopolies or estancos of any kind; nor exemption from taxes; nor prohibitions under pretext of protection to industry", except for a few designated activities such as mail and telegraph service. ${ }^{17}$ An estanco is a state monopoly established to benefit the treasury-similar to the Mercantilist monopolies exemplified by the Elizabethan sale of trade monopolies. ${ }^{18}$

This Adam Smithian view of the evils of governmentally sponsored monopolies did not hold up in subsequent practice. The law of Monopolies enacted in 1931 and $1934^{19}$ to put the constitutional provisions into effect exempted state-owned enterprises and enterprises in which the state is a shareholder.

Since then, Mexican policy has not shown much concern for competitive structure and behavior. Most Mexican administrations have been concerned with other economic goals-notably the goal of rapid development and retention of Mexican control of the economic destiny of the country. The combination of these aims has made the government decidedly paternalistic toward the economy. While it has allowed considerable latitude to private ownership and the free market, it has not demonstrated any consistent belief that competitive markets are the most effective means for achieving its ends. Instances to the contrary abound.

In 1935, the government issued a presidential decree allowing the Ministry of Industry and Commerce to authorize agreements and combinations among competitors for various purposes. ${ }^{20}$

In 1936, the Mexican Congress gave the president the power to declare an industry "saturated" and hence closed to further entry or expansion (the "law of Industry Saturation"). ${ }^{21}$

Later legislation enlarged the power of the government to intervene in markets

15. See United nations Conference on Trade and Development, Restrictive Business Practices, TD/122/Supp. 1 (1972).

16. La Constitucion Politica de los Estados Unidos Mexicanos y su ley Orgianica, 1927

17. Id.

18. Letter to the author from Professor William P. Glade, Jr., Director of the Institute for Latin American Studies at the University of Texas, September 5, 1980 [hereinafter cited as Glade].

19. Diario Oficial, Dec. 19, 1931 and Aug. 31, 1934 [hereinafter cited as D.O.].

20. Decreto of Nov. 23, 1935, published in D.O., Feb. 1, 1936.

21. See Glade, supra note 18. 
through tax incentives and price control, and to prohibit foreign ownership of industry and other property. ${ }^{22}$

A notable departure from the competitive market is Mexico's active policy of using government enterprise to organize economic activity. The best known of these enterprises, Petroleos Mexicanos (PEMEX) the Mexican government's oil monopoly, was created in 1938 when the foreign-owned petroleum industry was nationalized by the Cardenas administration. The immediate cause of this action was the refusal of the oil companies to comply with an order of the Mexican Supreme Court following a protracted and complicated labor dispute. The action, however, meshed well with the ongoing populist revolt against foreign control of Mexico's resources and with the philosophy of the dominant political party. It was not the result of a conscious choice of state monopoly as the best form of economic organization. "Mexicanization has been the paramount objective even where nationalization has been employed as a means to this end". ${ }^{23}$

Subsequent administrations have nationalized the railroads, the electric power industry, and other public utilities. The government has also largely created and controlled the indigenous system of banking and financing. ${ }^{24}$ A state-owned enterprise, FERTIMEX, currently produces about 90 percent of Mexico's fertilizer output ${ }^{25}$, and state-owned enterprise also produces basic petrochemicals. ${ }^{26}$ The number of state enterprises during the Echeverria administration (1970-1976) rose to several hundred, many of which seemed to be losing money.

Under existing circumstances it is not possible to contemplate a competitive oil industry in Mexico, even one owned by private Mexican interest. There is certainly no possibility for re-introduction of foreign-owned interests into the Mexican oil industry. The oil monopoly and a few others would be impervious to any North American antitrust policy, as would government monopolies in the other two countries. But sole monopoly is not always the aim of public enterprise in Mexico. For example, the government constructed a steel mill (Altos Hornos) in the early 1940s, and later established a holding company, SIDERMEX, to control it and several additional government steel properties. SIDERMEX, which produced about 62 percent of total Mexican steel output in $1980,{ }^{27}$ did not preempt the whole industry, but was designed to expand capacity, reduce imports, and stimulate more expansionary and innovative behavior by the publicly and privately-owned companies (i.e., to break down a restrictive oligopoly). ${ }^{28}$ These

22. I am indebted to Professor Glade for the information in the foregoing paragraphs. Glade observes, "The anti-monopoly provisions of the constitution have whatever meaning the president finds it convenient to give them at the time." Id.

23. W. Glade \& C. Anderson, The Political Economy of Mexico 75 (1963).

24. The Nacional Financiera, one of the institutions created by the government, has mobilized domestic capital and borrowed abroad to finance domestic industry at low rates of interest. It has tended to favor public enterprise and selected large-scale private firms in "priority fields." Sheahan, Public Enterprise in Developing Countries, in Public Enterprise: ECONOMIC ANAlysis of TheOry and Practicie. 210 (W. Shepherd ed. 1976).

25. Banco de Mexico, The Mexican Economy in 198038 (1980).

26. Id.

27. Getschow, Trouble at the Mill, Wall St. J., Jan. 27, 1981, at 1, col. 1.

28. Sheahan, supra note 24, at 212 (citing an unpublished Ph.D. dissertation by Norman Schncider). 
objectives are quite consistent with competitive markets, and antitrust policy could only applaud them.

\section{B. The Foreign Corporation in Mexico}

Foreign ownership and control of Mexican economic activity has been a leading issue in Mexico since the time of Porfirio Diaz. Economic xenophobia was a key ingredient in the Mexican Revolution of 1910. A large part of the concern with foreign control, though not all, has been focused on the intrusion of business interests from the United States. At first the problem was seen mainly as foreign control of Mexico's natural resources. Since the nationalization of oil and the strong assertion of governmental sovereignty over subsurface resources, it has acquired other dimensions. Foreign ownership of land is still perceived as a threat, and is still restricted in some areas. ${ }^{29}$ The activities of multinational corporations in the manufacturing industry and trade are an equally sensitive issue.

Multinational corporations have developed a considerable presence in Mexico. The MNCs based in the United States, Europe, and Japan that have entered the Mexican economy since World War II have sought: (i) to develop Mexican markets for their imported products through trading and marketing subsidiaries; and (ii) to produce goods and services (such as services to tourists) in Mexico itself. At first, as was true in most countries, MNCs began to manufacture in Mexico as a way of bypassing barriers to imports and to participate in import substitution in the domestic market. ${ }^{30}$ Later, some local manufacturing affiliates of MNCs became major exporters. In addition, some MNCs continued to export agricultural products and raw materials-survivals from an earlier day. The MNCs, because of their developed network of distribution channels and trade relations, were in a good position to develop export markets for some types of manufactured goods. ${ }^{31}$

Foreign control coupled with monopoly power has elicited protective reactions, but it should be noted that foreign control is the principal problem while monopoly is a secondary consideration. The alternatives to the MNC might well be local monopoly or a sponsored domestic cartel guarded by protective tariffs. ${ }^{32}$

29. Article 27 of the Mexican Constitution forbade ownership of land by foreign nationals in a one hundred kilometer strip along the frontiers or a fifty kilometer strip along the seacoasts of the country. However, the Foreign Investment Law of 1973 permitted foreigners to participate in limited land-holding trusts in the previously forbidden zone. [1973] MEXICAN FOR EIGN INVESTMENT AND TRANSHER (OF' TECHNOLOGY LAWS Art. 18 (CCH).

30. Mexico has made extensive use of quantitative barriers. In 1976, 85 percent of all her imports required a prior license. However, import license requirements have been eliminated for many products since then. A. Nowicki, Mexico: Manuracturing Sector: Situation, Prospects and Policies (1979), cited in Weintraub, Trade Integration of the United States, Canada, and Mexico in THE POLITICAL ECONomy of the Western Hemisphere: Selected Issues for U.S. Policy, 180 n.1 (Papers Prepared for the Joint Economic Committee, 97th Congress, 1981).

31. R. Vernon, Restrictive Business Practices: The Operation of Multinational United States ENTER PRises in Developing Countries 15-17 (1972)(Study Prepared For the U.N. Conference on Trade and Development). MNC subsidiaries in Mexico have not accounted for a disproportionate share of Mexico's exports, nor in general have they exported a larger fraction of their output than locally owned firms. See Jenkins, The Export Performance of Mulinational Corporations in Mexican Industry, 15:3 J. DEV. STU1). 89 (1979).

32. Cf. Rosenstein-Rodan, Problems of Private Foreign Investment and Multinational Corporations, in LATINAmERICAN-U.S. EcONOMIC InTERACTIONS 256-58, 265-66 (R. Williamson, W. Glade, Jr. \& K. Schmitt 
The kind of foreign control most disliked in Mexico is control from the United States. The background of this attitude is well-known: it encompasses fears of "imperialism" (old style) and "dependency" (new style). In 1975, the United States absorbed 60 percent of Mexico's exports and supplied 62 percent of its imports, with MNCs playing a significant role in both. ${ }^{33}$ Direct investment by the

TABLE 1
Share of Foreign Enterprises in the Value of Production of Manufacturing Industry, MeXico, 1970.

\begin{tabular}{|c|c|c|c|}
\hline $\begin{array}{l}\text { Group } \\
\text { Numbers }\end{array}$ & Industry Groups & & \\
\hline$(1975 \text { Codes })^{1}$ & & Of Total Output & $\begin{array}{l}\text { Of Output of the } \\
\text { "Modern } \\
\text { Segment" }\end{array}$ \\
\hline 20 & Food Products ..... & 8.6 & 26.5 \\
\hline 21 & Beverage industries. & 19.0 & 26.3 \\
\hline 22 & Tobacco products ....... & 79.7 & 84.0 \\
\hline 23 & Textiles $\ldots \ldots \ldots \ldots \ldots$ & 6.8 & 7.9 \\
\hline 24,251 & Footwear and clothing... & 2.0 & 4.0 \\
\hline 26,27 & $\begin{array}{l}\text { Wood products and fur- } \\
\text { niture } \ldots \ldots \ldots \ldots \ldots \ldots\end{array}$ & 7.2 & 15.9 \\
\hline 28 & $\begin{array}{l}\text { Paper and paper prod- } \\
\text { ucts } \ldots \ldots \ldots \ldots \ldots \ldots \ldots\end{array}$ & 27.4 & 32.9 \\
\hline 29 & Printing and publishing & 11.7 & 24.5 \\
\hline 252 & $\begin{array}{l}\text { Leather and leather prod- } \\
\text { ucts ................... }\end{array}$ & 1.7 & 4.6 \\
\hline 32 & $\begin{array}{l}\text { Rubber and plastic prod- } \\
\text { ucts ................ }\end{array}$ & 84.2 & 100.0 \\
\hline 30 & Chemical industry $\ldots . .$. & 67.2 & 77.8 \\
\hline 33 & $\begin{array}{l}\text { Nonmetallic mineral } \\
\text { products } \ldots \ldots \ldots \ldots \ldots\end{array}$ & 26.6 & 54.2 \\
\hline 34 & Basic metals $\ldots \ldots \ldots$ & 25.2 & 27.6 \\
\hline 35 & $\begin{array}{l}\text { Fabricated metal prod- } \\
\text { ucts } \ldots \ldots \ldots \ldots \ldots \ldots \ldots\end{array}$ & 37.0 & 67.6 \\
\hline 36 & Machinery (nonelectric) & 62.0 & 100.0 \\
\hline 37 & Machinery (electric) ..... & 79.3 & 100.0 \\
\hline 38 & $\begin{array}{l}\text { Transportation } \\
\text { equipment ............ }\end{array}$ & 49.1 & 100.0 \\
\hline 39 & $\begin{array}{l}\text { Miscellaneous } \\
\text { manufacturing } \ldots \ldots \ldots \ldots \\
\text { TOTAL } \ldots \ldots \ldots \ldots \ldots\end{array}$ & $\begin{array}{l}29.6 \\
27.6\end{array}$ & $\begin{array}{l}60.5 \\
44.7\end{array}$ \\
\hline
\end{tabular}

Source: Sepulveda A., Politica Industrial y Empresas Transnacionales en Mexico, in LAS EMPRESAS Transnacionales en Mexico 16 (B. Sepulveda A., O. De Brody, \& L. Meyer eds. 1974).

1. Group numbers from the industrial classification used in the Censo Industrial de Mexico were attributed by the author of this article, based on the industry descriptions given in the Sepulveda article. The petroleum products group (31) was not included in the Sepulveda tabulations.

eds. 1974). His paper deals with the MNC in Latin America generally, not just in Mexico. He notes that the MNC frequently helps to make local industry more efficient.

33. Ross, Mexican-U.S. Relations: An Historical Perspective, in U.S. Policies Toward Mexico: PerCEPTIONS ANd PERSPECTIVEs 5, 10 (R. Erb \& S. Ross eds. 1979). By 1979 the U.S. share of Mexico's exports had risen to 69 percent. BANCO DE MEXICO, supranote 25, at 69. 
United States in Mexico, amounting to $\$ 3$ billion by 1975 , accounted for 72 percent of total direct foreign investment. ${ }^{34}$ By contrast, Mexico supplied only 3.5 percent of U.S. imports in 1978, and absorbed only 4.6 percent of U.S. exports. ${ }^{35}$

Table 1 gives the most recent estimates available of the share of foreign-based MNCs in the total value of industrial production in 1970 by major industrial groups and their share of production in the "modern segment" of the Mexican economy as of ten years ago.

Surprisingly, the proportion of foreign investment in total private investment in Mexico has not been very large. It was estimated at 7.5 percent in the period 1962-70.36 Its real significance is its predominance in several of the most dynamic and technologically advanced sectors of the economy, where the advantage of the MNC is greatest.

\section{Concentration}

Do MNCs "import" monopoly into Mexican markets? Mexican perceptions of that question would probably have a significant bearing on their acceptance or rejection of an economic community which would give American and Canadian enterprises free access to their economy. It is very hard to find evidence that the structure of Mexican industry would be made more competitive by the removal of trade barriers.

Measures of concentration are not very good indicators of the extent of monopoly in an economy like Mexico's since they take no account of imports, balkanization of market territories, cartel agreements, or government controls. However, according to a conventional measure of concentration, the share of the largest four firms in the value of output of each industry, Mexican manufacturing industry is nearly as concentrated as that of the United States. The weighted average of fourfirm concentration in shipments of manufacturing and mining industries in Mexico in 1975 was 40 percent. ${ }^{37}$ For comparison, the weighted average four-firm ratio for manufacturing industries in the United States in 1972 was 39 percent. 38 The "highly" concentrated industries, those with four-firm ratios of over 80 percent, accounted for about 7 percent of the total value of Mexican manufacturing and mining output. ${ }^{39}$ They seem almost equally divided between those industry

34. Id.

35. Bureau of the Census, U.S. Dep't of Commerce, Highlights or U.S. Export anis Impokt Trade 33, 38 (1979).

36. Las Empresas Transnacionales en Mexico 38 (B. Sepulveda A., O. De Brody \& L. Meyer eds. 1974).

37. Collected from Secretaria de Programacion y Presupulsta, Direccion General ide EsTADistica, Censo Industrial, 1975 (1979) (by Centro de Investigaciones y Docencia Economicas, Mexico D.F., and calculated by Gustavo Trevino, a graduate student at the University of Texas) (hereinafter cited as CENSO INDUSTRIAL].

38. Bureau of the Census, U.S. Dep't of Commerce, 1972 Census of Manufactures: ConCentration Ratios in Manufacturing (1975).

39. About 34 billion from a total of about 500 billion pesos in 1972. See Censo Industrial, supra note 37. The proportion for industries with four-firm concentration ratios of over 70 percent was 14 percent. These proportions were roughly similar to those in the United States in 1972 for manufacturing industries having similar degrees of concentration. BUREAU OF THE CENSUS, supra note 38. 
groups dominated by foreign enterprise (such as flat glass, cigarettes, engines, vehicles, photographic equipment, telephone apparatus) and concentrated industries controlled by Mexican interests (such as some manufactured foodstuffs, furniture, nonferrous metals, footwear, sheets and carpets). ${ }^{40}$ In addition, the petroleum products industry is dominated by state-controlled enterprise, as are some other nonmanufacturing activities. ${ }^{41}$

In some technologically advanced manufacturing sectors, subsidiaries of foreign firms may still have a large market share resulting from their introduction of products or technology not previously produced or used in Mexico-products that Mexico would otherwise have had to import from foreign sellers who might have equally large market shares at home. Some industries, such as flat glass, seem to be highly concentrated everywhere.

Indigenous Mexican-controlled firms are just beginning to attain size levels comparable to the United States and Canadian giants. Of the 500 largest industrial firms in the world outside the United States in 1979, three were based in Mexico. PEMEX was the 39th largest. ${ }^{42}$ Grupo Industrial Alfa and Valores Industriales, two privately owned conglomerates, were becoming MNCs themselves, the Alfa group already operating in the United States. ${ }^{43}$ The leading export by Mexico to the United States is crude oil produced by the state monopoly. Petroleum exports would probably not be affected by creation of an economic community or common market. Quantities would depend entirely on what the Mexican authorities decided to send northward. The price of crude oil on world markets would be set by OPEC, which is beyond the reach of any antitrust policy. PEMEX itself might establish affiliates in the United States and Canada to handle downstream integration into refined products and petrochemicals. Few other opportunities are apparent for the intrusion of more Mexican MNCs into U.S. or Canadian markets, even after formation of a NAEC, that would give them a position remotely comparable to the position of foreign corporations in Mexico. However, such opportunities would grow over time.

\section{Policy Toward Foreign Investment and Control}

Mexican policy toward investment by foreigners, particularly multinational corporations, was codified in several statutes passed in 1972-1973. The chief statutes include the Law to Promote Mexican Investment ${ }^{44}$ and the Law for the Registration of the Transfer of Technology and the Use and Exploitation of Patents and Trade Marks. ${ }^{45}$ The provisions relevant to our question are discussed below. ${ }^{46}$

Foreign investors are not allowed to acquire more than 25 percent of a Mexican company's stock or 49 percent of its fixed assets without official permission.

40. CENSO INDUSTRIAL, supra note 37.

41. BANCO DE MEXICO, supra note 38 .

42. The Foreign 500, FORTUNE, Aug. 11, 1980, at 188.

43. Id.

44. See Mexico Tightens Up on Foreign Investment, Bus. Week, Apr. 28, 1973, at 94-98; D.O. Dec. 30,1972 and Dec. 28, 1973.

45. Id.

46. Id. 
Foreign takeovers of Mexican companies are not permitted. The basic petroleum and basic petrochemical industries, electric power, railroads, communication and some mining are to be government monopolies; radio and television broadcasting, coastwise sea and internal air transportation, and land development are reserved for Mexican nationals.

Other future foreign investments are limited by the statutes to 49 percent nonMexican participation, although the Investment Commission would allow up to 100 percent foreign ownership in ventures in critical industries or depressed areas. Foreign investments will be evaluated by such criteria as their contribution to exports, employment, and productivity. They cannot infringe on activities already well handled by Mexican investors. Foreign-owned manufacturing firms must agree to maximize the use of Mexican-produced components. The Commission will favor "diversification" of foreign investment, i.e., non-U.S. sources. (Most of these policies had been in effect for some time.)

No firm or affiliate in Mexico can make agreements with outside firms, including parents, to restrict exports to any country of products made with technology covered by the agreement. Nor will arrangements to import technology be approved if they restrict prices or production of goods in Mexico or obligate the Mexican firm to buy materials or equipment from the supplier of the technology.

Some of the provisions of these laws are protectionist at the expense of open competition, and thus would not assimilate easily into a continental antitrust policy. Entry of American and Canadian firms into protected industries would be barred. Most U.S. or Canadian entry into any Mexican industry would have to be via a Mexican-owned affiliate, primarily through a contractual relationship. But the prohibitions on tied markets or restricted use of technology would be quite consonant with a procompetitive policy for the continent.

A word should be added about the special arrangements in the Mexico-United States border region. Presently, U.S. firms can set up plants on the Mexican side, known as "maquiladoras", to utilize less expensive Mexican labor to assemble products for reshipment to the United States. A large number of "in-bond" plants have been created. The Mexican economy benefits from the additional employment in a depressed area. The present administration has made some efforts to set up maquiladoras in other sections of Mexico. An economic community would make such special arrangements unnecessary by extending free trade to the whole of the two countries and Canada.

It is doubtful whether Mexico would accept the kind of antitrust policy that would remove internal protection and open the economy to unlimited access by other North American-based business. Acceptance of free access to activities other than those reserved for government enterprise such as petroleum and utilities is only a little less doubtful. Paradoxically, free trade might well lessen the intrusion of U.S. and Canadian multinational corporations into actual in situ ownership and operation of business in Mexico itself, since many goods could then be supplied from sites farther north without restriction. But the probable effect in Mexican eyes would be very much the same: loss of infant-industry protection and abandonment of the policy of reserving as much of the Mexican market as possible for 
Mexican production, with a corresponding gain of foreign economic interests in Mexico. Neither the reciprocal opportunities for Mexican exports to the Northern countries, nor the improvement in the economic efficiency of internal markets, would appear to offer compensating attractions. If the improvement were due to entry by more foreigners, Mexicans would be apt to think of it as a monopolistic rather than a competitive effect.

\section{E. The Mexican Colossus}

Oddly enough, what looks like Mexican economic weakness when measured against the advanced industrial economies of the United States and Canada becomes intimidating strength when measured against some of the Latin American economies. It should not be forgotten that Mexico is a rapidly developing economy, far ahead of those of Central America and the Northern Andes. Its recent emergence as a major petroleum exporter provides further economic strength. In the future, Mexican multinational corporations, as well as public enterprises may play an important role in those countries. ${ }^{47}$ (Similar statements could be made about MNCs based in Brazil and Argentina.) Indeed, Mexico might see a more promising role for itself in a Latin American common market than in a North American one. Conversely, fear of the more advanced Latin American countries may help explain why the Andean Group and the Central American Common Market have apparently been more successful than the former Latin American Free Trade Association (LAFTA) which included the Big Three-Mexico, Brazil and Argentina. ${ }^{48}$

\section{III}

\section{A View of Canada's Position}

Canada's advanced economic development and its high levels of income should perhaps lead to attitudes toward proposals for economic integration different from those of Mexico. Certainly there are differences in viewpoint and in policy between the two countries, but on some issues, mostly those involving the United States, they are strikingly similar.

\section{A. Canadian Antimonopoly Policy}

Canadian federal policy is embodied largely in the Combines Investigation Act. Briefly, the essential applications are as follows: ${ }^{49}$

(I) Agreements and combinations that limit production, fix prices or enhance prices unreasonably, prevent competition, or restrain trade are illegal. Criminal penalties are pro-

47. "Even more familiar are the preoccupations of Bolivian and Honduran officials who may wonder whether it is a good idea to have so many Brazilians and Mexicans in their country and whether they are trading a first-rate imperial power for a second-rate one." Diaz-Alejandro, Foreign Direct Investment by Latin Americans, in Multinationals From Small Countries 179 (T. Agmon \& C. Kindleberger eds. 1977).

48. See R. VERNON \& L. Wells, ECONOMIC ENVIRONMENT OF INTER National BUSINESS 217.23 (2d ed. 1976). The Central American Common Market has itself suffered from internal dissension due to the uneven development of its members. See ECONOMic InTEgration In Centrall AmERIC: 34-42 (W. Cline \& E. Delgado eds. 1978).

49. Can. Rev. Stat. c. C-23 (1970). 
vided. Exchange of statistics and agreement on product standards, among other things, are not prohibited.

(2) Formation of monopolies, and mergers which are likely to lessen competition, are illegal.

(3) Price discrimination and predatory practices are illegal if they substantially lessen competititon or eliminate competitors. Resale price maintenance is prohibited.

(4) Restrictive Trade Practices Commission investigates possible violations, holds hearings, issues cease-and-desist orders, and reports cases to the Attorney General for enforcement in the courts.

The parallels between these laws and procedures and those of United States antitrust policy are obvious. Canadian policy seems to make greater use of criminal penalties and less of civil remedies ${ }^{50}$ than does that of the United States, but there would be little difficulty in reconciling the formal statutes and processes of the two countries under a North American Economic Community. The difficulties would tend to arise in the choice of targets. The 1975 amendments to the Combines Investigation Act specifically took aim at acts of multinational corporations. They prohibited or required modification in Canada of policies dictated by parties outside Canada - whether home offices, parent companies, or governments in their home countries - that would adversely affect competition in Canada or its foreign trade. ${ }^{51}$ As in Mexico, concern with foreign control is a leading issue in Canada.

\section{B. Foreign Investment and Control in Canada}

Foreign corporations have invested in Canada, either by establishing affiliates or by acquiring them, for the usual reasons: (i) to facilitate distribution of goods they manufacture elsewhere and import into Canada; (ii) to cross import barriers by manufacturing in Canada and marketing there; (iii) to secure an assured supply of raw materials by acquiring extractive properties in Canada; and (iv) to take advantage of lower factor costs in some industries by producing in Canada for export to other markets. Canada has offered very favorable opportunities for foreign investment of both portfolio and direct types, though problems for policy arise mainly from direct investment. Foreign investment has always been sizable. Before World War I, it was predominantly British; since then, predominantly American. In 1977, U.S. investment in Canada had a book value of over $\$ 65$ billion, and represented over 75 percent of all foreign investment in Canada. About 58 percent of U.S. investment was direct. ${ }^{52}$

The consequence of direct investment has been foreign control of a substantial part of the Canadian economy. Table 2 gives the percentage of foreign control of investment in various types of activity. U.S. control is particularly concentrated in manufacturing, (43 percent of the total value of assets in 1977); in oil and gas production (58 percent); and in mining (45 percent).$^{53}$

The influx of foreign investment was generally welcomed in Canada until the

50. One special remedy for monopoly is admission of the product to Canada free of import duty. Can. Rev. Stat, c. C-23, 28 (1970).

51. Organization for Economic CoOperation and Development, Restrictive Practices Of Multinational Enterprises 35-36 (1977) (Refers to sections 31.5 and 31.6 of the Act).

52. Gherson, U.S. Investment in Canada, 3 Foreign Investment REv. 2, 11 (Spring, 1980).

53. Id. at $12,13$. 
1960s, when the government and the public began to develop serious reservations about U.S. control. Governmental questions about foreign ownership culminated in the so-called Gray Report in 1971. The consequence of the Report and the deep public misgivings that precipitated it was the Foreign Investment Review Act of 1973. ${ }^{54}$ This Act set up an Agency (FIRA) to review and disallow foreign takeovers of Canadian businesses and, by amendment in 1975, establishment of new businesses by non-Canadian interests. The criterion for approval was that the proposal must show "significant benefit" to Canada-in new employment, enhanced

TABLE 2

Foreign Control in Canadian Nonfinancial Industries, 1970 and 1977

\begin{tabular}{|c|c|c|c|}
\hline \multirow[t]{2}{*}{ Group } & \multicolumn{2}{|c|}{$\begin{array}{l}\text { Percent of Foreign } \\
\text { Control of Assets }\end{array}$} & \multirow{2}{*}{$\begin{array}{c}\text { Asset Value, } \\
1977 \\
\text { (Can. \$ Millions) }\end{array}$} \\
\hline & 1970 & 1977 & \\
\hline Mining $1 . \ldots \ldots$ & 69 & 51 & 35,886 \\
\hline Manufacturing ${ }^{2} \ldots$ & 58 & 54 & 95,414 \\
\hline Primary metals & 43 & 14 & 8,670 \\
\hline Wood products & 33 & 21 & 4,126 \\
\hline Chemicals ........... & 80 & 68 & 7,722 \\
\hline Machinery & 75 & 64 & 3,742 \\
\hline $\begin{array}{l}\text { Leather products } \ldots \ldots \\
\text { Transportation }\end{array}$ & 30 & 20 & 448 \\
\hline equipment $\ldots \ldots \ldots$ & 85 & 77 & 8,324 \\
\hline Metal fabricating .... & 47 & 40 & 5,652 \\
\hline Furniture $\ldots \ldots \ldots \ldots$ & 21 & 16 & 903 \\
\hline Petroleum and coal & & & \\
\hline products $\ldots \ldots \ldots \ldots$ & 96 & 92 & 13,442 \\
\hline Printing, publishing ... & 15 & 11 & 2,480 \\
\hline Paper $\ldots . . \ldots \ldots \ldots$ & 43 & 39 & 12,016 \\
\hline Knitting mills $\ldots \ldots \ldots$ & 21 & 18 & 374 \\
\hline Miscellaneous & 51 & 48 & 2,642 \\
\hline Beverages $\ldots \ldots \ldots \ldots$ & 32 & 31 & 2,420 \\
\hline Clothing $\ldots \ldots \ldots \ldots$ & 14 & 14 & 1,308 \\
\hline Rubber products..... & 93 & 94 & 1,438 \\
\hline Food products $\ldots \ldots \ldots$ & 36 & 39 & 7,336 \\
\hline Electrical products .... & 65 & 69 & 4,875 \\
\hline Textiles..$\ldots \ldots \ldots$. & 52 & 58 & 2,476 \\
\hline Nonmetallic mineral $\therefore$ & 63 & 70 & 3,998 \\
\hline Tobacco products..... & 86 & 100 & 1,022 \\
\hline Agriculture, Forestry, Fish- & & & \\
\hline ing $\ldots \ldots \ldots \ldots \ldots \ldots$ & 13 & 8 & 4,063 \\
\hline Services...$\ldots$. & 22 & 18 & 21,250 \\
\hline Construction. . . . . . . $\ldots$, & 16 & 12 & 16,305 \\
\hline Trade $\ldots \ldots \ldots \ldots \ldots \ldots$ & 25 & 22 & 49,360 \\
\hline Utilities $\ldots \ldots \ldots \ldots \ldots$, & 8 & 7 & 81,662 \\
\hline Total nonfinancial $\ldots \ldots \ldots$ & 36 & 30 & 303,940 \\
\hline
\end{tabular}

1. Including nonintegrated oil and gas producers.

2. Manufacturing groups are arranged in decreasing order of gain in Canadian control, 1970-77, as in the source tables.

Source: Gherson U.S. Investment in Canada, 3 Foreign InVestment Rev. 2 (Spring, 1980).

54. Foreign Investment Review Act, 1973, c. 46. 
productivity, improved technology, etc. The effect on competition was to be evaluated as well. ${ }^{55}$ During the first five years the Government decided over 1650 FIRA cases; 130 proposals were disallowed. Over 90 percent were approved. Reasons for disapproval of takeovers included restriction on Canadian exports or on importation of technology to the detriment of home development. ${ }^{56}$

The similarities of the Canadian and Mexican policies are evident, as is the extent of their trade interdependencies with the United States. In the mid-1970s, about 69 percent of Canada's imports came from the United States; about the same proportion of her exports went to the United States. ${ }^{57}$

These trade relationships, as well as the activities of multinational corporations, are bound to influence the formation and operation of any North American Economic Community in many ways other than their impact on competition and policy toward monopoly. However, it is instructive to look at Canadian industrial concentration and its relation to foreign control before speculating on the effects of removing barriers to U.S. imports and investment in Canada.

\section{Concentration and the Multinational Firm}

The Canadian economy exhibits high-to-moderate concentration, somewhat higher than that in the United States. In 1972, about twice as many industries had four-firm concentration levels exceeding 60 percent in Canada as in the United States. ${ }^{58}$ The nine largest manufacturing industries in Canada were all more concentrated than their counterparts south of the border. ${ }^{59}$ Overall, the 50 largest non-financial Canadian corporations in 1973 accounted for 32.4 percent of total assets and 15.0 percent of total sales. ${ }^{60}$

In the manufacturing sector, the 50 largest Canadian firms had 31.7 percent of total sales in 1973 and the 100 largest had 39.1 percent. ${ }^{61}$ For comparison, in the United States in 1972 the 50 largest manufacturing corporations accounted for 24.5 percent of total value added by manufacture and the 100 largest for 33.1 percent. ${ }^{62}$

It is not easy to determine whether U.S.-controlled multinational corporations have contributed to a problem of structural monopoly in Canadian markets, but

55. Id.

56. The Foreign Investment Review Act, Address by the Hon. Jack Horner, Minister of Industry, Trade and Commerce to the Toronto Society of the Investment Dealers Association of Canada, (Feb. 7, 1979).

57. CANADA YEAR BOOK 871 (spec. ed. 1976). In 1978, about 20 percent of U.S. exports went to Canada, and about the same proportion of U.S. imports came from Canada. BUREAU OF THE CENSUS, U.S. DeP'T OF Commerce, STatistical Abstract of THE United STates (1980).

58. Report of the Royal Commission on Corporate Concentration 39-41 (1978) [hereinafter cited as ROYal COMmission]; see also BUREAU OF THE Census, supra note 38.

59. Royal Commission, supra note 58.

60. Organization for ECONOmic CoOperation and Development, Concentration and Competition Policy 78 (1979).

61. Id.

62. Id. at 84 . 
TABLE 3

\section{U.S. Control of Largest Canadian Companies, 1979}

Size Group
(Ranked by 1978-79 Sales) $\quad \begin{gathered}\text { U.S. Share of Ownership } \\ \text { Over 50\% }\end{gathered}$

they are certainly represented among the largest firms doing business in Canada, as shown in Table 3. The Royal Commission on Corporate Concentration found a ". . . strong direct correlation between the degree of foreign ownership and the degree of concentration and the presence of large firms. The degree of foreign ownership is very high in those industry segments where an oligopoly of three or four firms account for a high proportion of total sales in the industry." 63 But it concluded that foreign direct investment ". . . does not seem to have increased the concentration of industries in Canada." 64 Canadian industries with a high percentage of foreign ownership were no more concentrated than similar industries with lower foreign ownership in other countries. And some of the most concentrated industries in Canada (e.g., cotton cloth manufacture) had relatively low foreign shares. ${ }^{65}$

Thirty of the largest industrial firms in Canada (which are among the 500 largest in the world outside the United States) are listed in Table 4, along with the apparent location of their control. The largest U.S.-controlled firms in Canada, as in the United States, are in motors, oil, chemicals, and electrical equipment; presumably those firms would be large and their sectors concentrated even if they were under Canadian control. Several, in fact, have made the transition to Canadian control as indicated in Table 4.

It is noteworthy that a sizable proportion of the large Canadian-controlled firms in Table 4 are multinationals that have susidiaries in the United States. Examples are Noranda Mines, MacMillan Bloedel (paper and wood products),

63. Royal Commission, supra note 58, at 192. For an earlier study, see Rosenbluth, The Relation between Foreign Control and Concentration in Canadian Industry, 3 Canadian J. ECON. 14, 17 (1970).

64. Royal Commission, supta note 58, at 194.

65. Id. at 38 . 
TABLE 4

The Largest Industrial Corporations in Canada, 1979 (RANKed by SALES)

\begin{tabular}{|c|c|c|c|c|}
\hline & Name & Control ${ }^{1}$ & Sales $(\$ 000)$ & Assets \\
\hline 1. & General Motors of Canada. & A & $8,032,990$ & $1,902,705$ \\
\hline 2. & Canadian Pacific $\ldots \ldots \ldots \ldots \ldots \ldots$ & C & $6,957,492$ & $9,416,618$ \\
\hline 3. & Ford Motor Co. of Canada........ & A & $6,103,129$ & $2,001,195$ \\
\hline 4. & Imperial Oil $\ldots \ldots \ldots \ldots \ldots$ & A & $5,484,040$ & $3,984,075$ \\
\hline 5. & Alcan Aluminum. & $\mathrm{C}^{2}$ & $4,381,222$ & $4,490,213$ \\
\hline 6. & Massey-Ferguson & C & $2,972,966$ & $2,745,444$ \\
\hline 7. & Gulf Canada .... & A & $2,567,016$ & $2,814,101$ \\
\hline 8. & Inco $\ldots . . . \ldots .$. & $\mathrm{C}^{2}$ & $2,488,543$ & $4,335,389$ \\
\hline 9. & Texaco Canada . . . . . . . . . . . . . . . & A & $2,252,540$ & $1,968,273$ \\
\hline 10. & Chrysler Canada . . . . . . . . . . . . . & A & $2,180,224$ & N.A. \\
\hline 11. & Noranda Mines $\ldots \ldots \ldots \ldots \ldots \ldots$ & $\mathrm{C}$ & $2,121,130$ & $2,841,668$ \\
\hline 12. & Canada Packers $\ldots \ldots \ldots \ldots \ldots \ldots$ & $\mathrm{C}$ & $2,011,810$ & 389,233 \\
\hline 13. & MacMillan Bloedel ............... & C & $1,861,294$ & $1,448,100$ \\
\hline 14. & Steel Co. of Canada $\ldots \ldots \ldots \ldots \ldots$ & $\mathrm{C}$ & $1,785,227$ & $2,066,923$ \\
\hline 15. & Canada Development Corp. ........ & $\mathrm{C}^{3}$ & $1,720,090$ & $2,369,001$ \\
\hline 16. & Northern Telecom . ................ & $\mathrm{C}$ & $1,622,438$ & $1,612,903$ \\
\hline 17. & Seagram $\ldots \ldots \ldots \ldots \ldots \ldots \ldots$ & C & $1,607,728$ & $2,437,076$ \\
\hline 18. & Moore $\ldots \ldots \ldots \ldots \ldots \ldots \ldots \ldots$ & C & $1,541,048$ & 968,099 \\
\hline 19. & International Thomson & C & $1,484,565$ & $1,252,565$ \\
\hline 20. & Domtar ............. & C & $1,276,567$ & 836,213 \\
\hline 21. & Abitibi-Price $\ldots \ldots \ldots \ldots \ldots \ldots \ldots$ & C & $1,255,686$ & $1,013,092$ \\
\hline 22. & Dominion Foundries \& Steel $\ldots .$. & C & $1,225,080$ & $1,429,085$ \\
\hline 23. & Canadian General Electric . . . . . . & A & $1,142,847$ & 773,833 \\
\hline 24. & Consolidated-Bathurst $\ldots \ldots \ldots \ldots$ & C. & $1,062,244$ & 848,898 \\
\hline 25. & Husky Oil . . . . . . . . . . . . & C & 898,907 & 957,306 \\
\hline 26. & Molson $\ldots \ldots \ldots \ldots \ldots \ldots \ldots \ldots$ & C & 885,059 & 542,908 \\
\hline 27. & John Labatt .................. & C & 819,925 & 534,306 \\
\hline 28. & Dome Petroleum $\ldots \ldots \ldots \ldots \ldots \ldots$ & $\mathrm{C}^{2}$ & 807,125 & $2,679,295$ \\
\hline 29. & H. Walker-Gooderham \& Worts ... & C & 768,553 & $1,168,941$ \\
\hline 30. & DuPont Canada ................... & A & 750,573 & 491,014 \\
\hline
\end{tabular}

1. $\mathrm{A}=\mathrm{U} . \mathrm{S}$. controlled; $\mathrm{C}=$ Canadian controlled, as determined from annual reports. There is noncontrolling American portfolio investment in many of the Canadian-controlled firms.

2. Formerly, A.

3. Government-controlled.

Source: The Foreign 500, FORTUNE, Aug. 11, 1980, at 188, 190-99.

Note: Shell Canada is not shown since Fortune consolidates it with Royal Dutch Shell, a British/Dutch corporation; it would probably be among the largest firms in this table.

Husky Oil, and Hiram Walker (No. 29), which, in addition to operating its distilled-spirits business, was seeking to acquire a U.S.-based oil company for over $\$ 1$ billion in late $1980 .{ }^{66}$ Northern Telecom, a subsidiary of the Canadian Bell Telephone Company, has aggressively entered the U.S. market for data processing and data communications equipment (in which the leading U.S. telephone company until recently could operate only on a restricted basis) and has acquired U.S. manufacturing affiliates such as Data 100 and Sycor. Alcan Aluminum, formerly a

66. Zehr, Hiram Walker Seeks U.S.-Based Oil Finm and is Willing to Spend Over \& I Billion, Wall. St. J., Oct. 15, 1980, at 18. Zehr also notes that Hiram Walker's planned acquisition of Highland Distilleries Co., Glasgow, Scotland, was rejected earlier in 1980 by Britain's Monopolies and Mergers Commission. 
subsidiary of Alcoa, has acquired or built several aluminum fabricating plants in the United States. International Thomson has acquired newspapers in Ohio. Joseph E. Seagram has long been one of the largest distillers and marketers of spirits and wine in the United States. In 1974, Canadian interests owned 457 manufacturing plants in America, out of a total of 2,053 foreign-owned plants listed by the Department of Commerce. ${ }^{67}$ So far there has been no public outcry against Canadian ownership.

The value of Canadian direct investment in the United States had reached almost Can. $\$ 5$ billion in 1974 , only a fraction of the Can. $\$ 29$ billion American direct investment in Canada, but somewhat larger than the American direct investment in Mexico. ${ }^{68}$

One can only speculate on what would remain of the Foreign Investment Review Act and similar policies in a North American Economic Community. Could acquisition of Canadian business by American firms then be left entirely to antitrust restrictions in Canada? The Canadian government might well enforce a policy within NAEC requiring majority Canadian ownership or control of affiliates of American firms. Some acquisitions or extensions could be checked by the Community's antitrust policy, but probably not enough to satisfy Canada's wish to minimize foreign ownership.

In fact, some acquisitions in Canada by American corporations in the past have been vetoed by American antitrust policy. For example, in 1966 a U.S. Court forbade acquisition by the Schlitz Brewing Co. of John Labatt, Ltd., a Canadian brewery. Another court prevented Standard Oil Co. of New Jersey from acquiring the Potash Co. of America, a producer of potash in both countries, because the latter competed in Canada with Imperial Oil Ltd., a Standard Oil affiliate and a potential supplier of potash to the U.S. market. However, the Canadian government has occasionally objected to American antitrust orders that affect Canadian firms, as when a U.S. court ordered Alcoa to divest itself of its control of Aluminum Company of Canada in 1950. A similar conflict arose in 1951 when DuPont was forced to divest itself of ownership of Canadian Industries, which it had owned jointly with Imperial Chemical Industries, Ltd. ${ }^{\circ 9}$

\section{Canadian Protectionism and Special Relationships}

The policy embodied in the Foreign Investment Review Act is only one of several aspects of Canadian protectionism and related policies that might compel

67. E. Fry, FINANCIAL INVASION OH THE U.S.A. 60 (1980). Fry also notes that a considerable share of real-estate development in the United States, especially in Florida, is now being conducted by Canadian investors. "Cadillac Fairview Corporation, Canada's biggest real estate developer, is bulding office towers in San Francisco and Denver, three California industrial parks, three Florida housing projects, and severa! shopping centers scattered across the United States." Id. at 112. These, however, do not seem to present any question of concentration or monopoly.

68. Globerman, U.S. Ownership of Firns in Canada, Canada-U.S. Prospects 7 (1979). It should be added that some Canadian exterior investment is by Canadian firms controlled in the United States-but probably not much in the United States itself.

69. Leyton-Brown, The Multinational Enterprise and Conflict in Canadian-American Relations, 28:4 IN''L. ORGANILATION 739 (1974). 
special exceptions to a free-trade, free-investment Community agreement. Canadian tariffs on manufactured imports are comparatively high, and they are buttressed by quotas and other restrictions. ${ }^{70}$ "The tariff combined with foreign ownership-which is itself a product of earlier tariff policy-has produced or maintained a basically inefficient industrial structure with truncated branch plants producing too large a range of goods . . . for too small a market."71 A free trade agreement would force such industries to compete more effectively in order to survive, but those effects would result from trade policy rather than antitrust policy. Without trying to speculate on what special exemptions from free trade would be worked into an integration agreement, we can identify some sectors that might well, in the Canadian view, call for special protection from a NAEC antitrust policy.

The famous Auto Pact of 1965 was itself a movement toward freer trade, but with protectionist safeguards. The Canadian government virtually abolished tariffs on automobiles imported from the United States in exchange for commitments from U.S. auto manufacturers that they would increase the volume of output in their Canadian affiliates and purchases from independent Canadian suppliers, by more than the growth rate in the Canadian market. Though the arrangement involves a form of market allocation and production quotas, its replacement by unrestricted free trade would not be welcomed by the Canadian authorities of their constituent economic interests.

Another sector that is not likely to return to a regimen of unrestricted private market competition is energy. ${ }^{72}$ The Canadian government has taken control of oil and gas exports and imports. It has virtually phased out export of crude oil to the United States (in the early 1970s oil was one of the leading Canadian exports ${ }^{73}$ ) and has sharply restricted any further commitments to export natural gas, while establishing a two-price system for exports and internal consumption. In 1975 it set up a government controlled corporation, Petro-Canada, which is not to be a sole monopoly after the example of PEMEX but is expected to become the largest company in the Canadian petroleum industry. Petro-Canadian has acquired a number of properties that were formerly U.S.-controlled (Atlantic Richfield Canada, Pacific Petroleum).

The oil industry in Canada has recently come under fire from Canadian antitrust authorities for its "monopolistic practices" including alleged overcharges on

70. In the near future, as a result of the Tokyo Round of GATT, some 65 percent of Canadian imports from the United States will be free of duty. (And 80 percent of U.S. imports from Canada will be duty-free, up from 60 percent in 1978.) Cohen, Constants and Variables in Canada-U.S. Relations. INT'L PERSPECTIVES 4 (Nov./Dec. 1980). But Canadian duties are not only higher on the average than U.S. tariffs; they are concentrated in manufacturing having high value added.

71. Standing Senate Comm. on For. Arfalrs, Ganada-United States Relations, Canada's Trade Relations With THE UNITED STATES, VOL. II, 116 (1978) cited in Weintraub, supra note 30, at 187 n. 12.

72. See McKie, United States and Canadian Energy Policy in Oil in the Seventies: Essay's ON ENERGY POLICY 245 (C. Watkins \& M. Walker eds. 1977).

73. Canadian Year BoOK 715 (1974). 
transfer prices for imported crude and excessively high refining margins. ${ }^{74}$ The targets are four multinational companies-Imperial (Exxon), Gulf, Texaco, and Shell Canada, the first three controlled in the United States. These four companies controlled 64 percent of Canadian refining capacity in 1979 and 56 percent of the country's retail outlets in 1980-a substantially greater concentration than in the United States. ${ }^{75}$ Opening up the Canadian oil market to North American free trade would decrease concentration but probably would increase foreign penetration. ${ }^{76}$

In October, 1980, the Federal Government announced plans to increase Canadian government and private ownership and control of oil and gas properties to 50 percent (up from 30 percent at the time). Petro-Canada was to have preemptive rights to 25 percent of all oil and gas discovered on Federal lands in the future, and the government itself would finance the purchase of interests in multinational oil companies with Canadian holdings so as to raise Canadian participation in their affiliates to at least 50 percent. Direct takeover by Petro-Canada of several multinational affiliates in Canada was anticipated. ${ }^{77}$ The plans would also require maximum use of Canadian goods and services by the oil industry-a rule that would probably conflict with GATT as well as with any general NAEC antitrust policy. The U.S. government has strong objections to these new plans. ${ }^{78}$

Earlier that same year Canada and Mexico concluded a government-to-government agreement to sell 50,000 barrels per day of Mexican oil to Canada in exchange for a Canadian commitment to aid Mexican economic development with joint investments, assistance in transfer of technology, and $\$ 430$ million in credits for export of capital equipment to Mexico. ${ }^{79}$

As in Mexico, a North American Community antitrust policy would necessarily exempt petroleum - and probably other Canadian energy industries as well, deferring to government preemption of policy.

Still another exemption would probably be granted to commodity agreements or government-sponsored cartels. Canada has a major interest in the export of raw materials and agricultural commodities. It has been a party to the several International Wheat Agreements, as has the United States. Although Canada refused to participate in producer associations in iron ore, copper, mercury, silver and tungsten during the 1970s it apparently did participate in the uranium cartel before 1975 , and allegedly even pemitted Canadian uranium producers to infringe the Combines Investigation Act. ${ }^{80}$ Canadian sources claim that these actions were

74. Urquhart, Major Changes in Canadian Oil Industry Sought After 7 Year Antitrust Inquiny, Wall. St. J., Nov. 5,1981 , at 18 , col. 1 .

75. Id.

76. $I d$.

77. Id.

78. Urquhart, Canada Drive, Wall St. J., Feb. 18, 1981, at 1, col. 1.

79. Giniger Mexico to Sell Oil to Canada, New YORK Times, May 28, 1980, at D-5, col. 1.

80. Stewart, Canada and the Uranium Carlel, INT'L Perspectives, 21,22 (July/August 1980). However, the Canadian government subsequently decided to prosecute for antitrust violations the very companies that it had encouraged to participate in the cartel, including two state-owned companies. Urquhart, Commodities, Wall St. J., June 24, 1981, at 34, col. 1, confirmed in Six Canada Producers of Uranium Charged in Antitrust Case, Wall St. J., July 8, 1981, at 18, col. 1. 
taken in response to American protectionist policies. The Canadian government has declined to make information available to contending parties in a U.S. antitrust suit involving the uranium cartel. ${ }^{81}$

The East Coast Fisheries Agreement between Canada and the United States, currently in limbo, is an example of the kind of bilateral trade and commodity agreement that recognizes a special status for certain activities and implicitly would shelter it from the full impact of a NAEC antitrust policy. ${ }^{82}$

\section{IV}

\section{Meshing Economic Integration with U.S. Antitrust Policy}

Integrating antitrust policy into a North American Economic Community of the kind contemplated would probably be less difficult in the United States than elsewhere on the continent. Apart from the inevitable protected activities, economic policy in the United States would not conflict in decisive ways with a NAEC antitrust policy, nor with free trade and free investment from other members of the community. If anything, antitrust policy on the EEC model would be less restrictive than that already in effect within the United States. Many of the U.S. rules are much the same as those of the EEC (e.g., price fixing, market allocation, quotas, price discrimination, and mergers that would enhance the power of dominant firms).

In a broad sense, free trade would increase the competitiveness of markets in the United States, since cheaper sources in Canada and Mexico could reduce prices in any market previously protected by tariffs. But most products in which Mexico or Canada now have a comparative advantage are sold in markets that already have a competitive structure, and a large proportion of those products come in free or nearly free of duty at present. Many of the really concentrated industries in the United States, which produce such products as automobiles (already subject to special agreement with Canada), light bulbs, plate glass, ready-toeat breakfast cereals, home washing machines, steel boilers, cathode ray tubes, roller bearings and space satellite communication systems ${ }^{8.3}$ would probably not initially feel much more competition from sources in Canada and Mexico, where such products are more than likely to be produced by a branch plant of an American firm. The Canadian-controlled large firms in Table 4 are mostly in the extractive industries, in non-export activity or in less concentrated manufacturing industries. But there are exceptions, and as time goes on some concentrated American markets may benefit from additional competition, e.g. , from Canadian aluminum products and machine tools or Mexican beer and vinyl tile.

The policy of repatriating ownership and control of industry from multina-

81. See Stewart, supra note 80

82. The Fisheries Agreement had major national political and economic significance for Canada, but its ratification was blocked by a few U.S. Senators because of objections by strictly local economic interests, leading Canadians again to complain about the differences in "perspective." Such episodes add weight to Canadian objections to North American economic integration.

83. These products classes all had concentration ratios (the percentage of total shipments accounted for by the largest four manufacturers) over 80 percent in 1972. U.S. BUREAU OF THE CENSUs, supra note 38 . 
tional corporations in those two countries should also create new competition in the American market from those former affiliates that can survive and grow from branch-plant status to fully developed firms on a par with their former parents. At present we do not know how many potential rivals exist in Mexico and Canada. Some affiliates of MNCs could not survive open competition but would in time be replaced by exports from U.S. plants. These, of course, might seek protection of some sort.

To date there has been no major American initiative to restrict investment by multinational corporations, especially those controlled in Canada and Mexico. ${ }^{84}$ The MNC is not perceived as a carrier of monopoly power transmitted from outside the country. U.S. policy at present would find it unnecessary to impose any general requirement of domestic ownership or control of Canadian or Mexican firms operating within its borders.

Export-import trade among the three countries would encounter some new competitive conditions under NAEC antitrust policy. Except where specifically exempted from the rules against price-fixing, groups of exporters within the NAEC could no longer agree to limit exports or adhere to common prices. The new antimonopoly policy would override some difficult problems of jurisdiction for American antitrust enforcement against Canadian and Mexican firms, since the NAEC would not be limited to the reach of a single sovereignty. ${ }^{85}$ At the same time it would probably kill off any Webb-Pomerene export associations operating primarily in North America.

The United States would undoubtedly reserve certain sectors of economic activity for special treatment, as it has from its own antitrust laws. Regulated monopolies, communications and transportation would probably require modification of a competitive policy. Like almost all countries, the United States would continue governmentally-sponsored cartel practices in agriculture (price fixing, marketing agreements, quotas, production controls, subsidies, etc.) subject to general trade rules negotiated for the NAEC as a whole.

Certain subsidized or sensitive energy industries, notably nuclear power, might be protected against competition within the Community. Finally, the U.S. Government has long allowed special exemptions from antitrust rules for defense industries, which would doubtless continue-a significant exception because of the magnitude of defense material production in the United States.

84. Sporadic attempts to limit or forbid acquisition of land and other property by Arab interests have occurred, but these are directed neither at MNCs as such nor at monopoly power. Some uneasiness has resulted from growing Japanese direct investment. In 1974 Congress passed the Foreign Investment Study Act directing the Commerce and Treasury Departments to investigate the problem, but the resulting reports in 1976 found no significant threat in foreign investment. See Fry, supra note 69, at 5-6.

85. There are cases on record of U.S. prosecution of American firms that attain monopoly elsewhere. In Uniled States v. Sisal Sales Corp., 274 U.S. 268 (1927), defendant had secured a monopoly of sisal in Mexico, with only indirect effects on the domestic market via imports. And in Uniled States $v$. Aluminum Co. of America, 148 F.2d 416 (1945), a Canadian affiliate (Alcan) was held to have violated the Sherman Act because of its agreement with European aluminum producers not to export to the United States market. 


\section{THE IMPACT OF NORTH AMERICAN ANTIMONOPOLY POLICY}

\section{A. Improvements in Competition}

What improvements in competition could be expected from a NAEC antitrust policy? Most of the improvements in competitive performance (or in economic efficiency of resource allocation as conventionally defined) would result from freer trade. But there might be a visible incremental impact from a NAEC antimonopoly policy on several kinds of practices and even on market structure.

Rules like those of the EEC would certainly restrict the formation of cartels and agreements affecting the North American market, unless the agreements were sponsored by the governments of the constituent states. However, it is not evident that any private cartels now exist that would be eliminated by such a policy. Agreements such as the Auto Pact are agreements among governments, and hence would be exempt. If new commodity agreements in the ten "core commodities" suggested by UNCTAD in $1975^{86}$ were organized, several commodity agreements such as one of coffee, would include exports from Mexico, and others on the potential list might involve both the United States and Canada. These would be immune. But any such program that excluded or injured producers or consumers in another North American country would undoubtedly have to be reconstructed to protect the interest of all NAEC members. It is possible that stronger export associations for a limited group of products produced in two or more of the North American states could be formed to compete in other markets more effectivelypetrochemicals is an obviously eligible case-but that has little to do with competition within the NAEC.

If the Community has policies and rules to restrict structural monopoly, they could be as mild as the EEC rules or as strict as a combination of Section 2 of the Sherman Act and Section 7 of the Clayton Act-antimonopoly and antimerger rules on an international scale. We cannot predict how the NAEC might approach international structural monopoly, but we can guess that Canada and Mexico, especially the latter, would insist on some sort of restraints on monopoly power that they perceive as emanating from the United States. Presumably each country would continue its restraints on the behavior and policies of the foreign multinationals, specifically:

(1) Restraints on the international allocation of markets among affiliates of a MNC, and/or such practices as prohibition of exports;

(2) Restraints on pricing "abuses" by MNCs, such as price discrimination among countries, grossly artificial transfer prices for imports and exports among affiliates, etc.;

(3) Prohibition of restrictive clauses in patent licenses; and

(4) Control of acquisitions of domestic firms by foreign MNCs. ${ }^{87}$

86. The UNCTAD "Core" list included cocoa, coffee, cotton, copper, hard fibers, jute, rubber, sugar, tea, and tin. McNicol, Political Economy of an Integrated Commodity Program, in STABILIzING World CoMMODITY MARKeTS 196 (F. Adams \& S. Klein eds. 1978), citing Resolution 93 (IV) of the Fourth U.N. Conference on Trade and Development.

87. Cf. the litany of practices in OECD, Restrictive Business Practices of Multinational. ENTERPRISES, supra note 51, at 27. This report observes: "[M]ultinational enterprises typically operate on 
If these Mexican and Canadian policies continued to preempt these issues from NAEC antitrust policy, the latter would have two remaining roles relating to single-firm monopoly: (i) to protect the U.S. market from similar effects emanating from Canadian and Mexican MNCs-hardly a major problem as yet, but perhaps a future threat; and (ii) to restrain the unilateral exercise of power by private monopolies in each country of the NAEC that export to or import from another (i.e., at arm's length, not through affiliates).

If Canada and Mexico believe that trade monopoly and monopsony based in the United States and not operating through MNCs are threats to their economic welfare, they might welcome that arena as one for NAEC antitrust enforcement. It would probably be extraordinarily difficult for a NAEC antitrust authority to enforce any policy of structural reorganization of firms located wholly within the United States (or Canada or Mexico) if those firms had escaped antitrust dissolution at the hands of their national governments; but the NAEC could control international price discrimination and predatory practices in North American trade.

\section{B. Asymmetry as the Stumbling Block}

Antimonopoly policy illustrates again the problem that runs through all aspects of any North American economic union-the considerable discrepancies in size, power, and (in the case of Mexico) stage of development among the three North American countries. The words of Harry G. Johnson fifteen years ago are pertinent:

[A] country will be motivated to join the union only if it judges that its industrial competitiveness or comparative advantage in industrial production is strong enough for its industrial production to increase within the union. . . . Consequently, customs unions are most likely to be negotiable among countries with a similar degree of preference for industrial production, and with a similar degree of comparative advantage in industrial production, or, as it is sometimes put, countries at a similar stage of economic development. ${ }^{88}$

If all three countries had similar market structures, and if the transmission of competitive and anticompetitive influences across their mutual borders were random and roughly symmetrical, then an enlarged antitrust policy would be a positive incentive for the formation of a North American Economic Community. If all three countries perceived the threats of monopoly from outside North America as greater than the threats originating within, then again we could expect them to draw together on a competition policy. But under the circumstances, Canada and Mexico evidently perceive the danger of economic domination from the United States as greater than any monopoly originating outside the continent, and have adapted their policies accordingly. In this writer's opinion, Canada and (especially) Mexico are likely to act on the belief that they have more to gain from staying aloof from a NAEC and relying on bilateral negotiations, government intervention and control, and their own protectionist policies as safeguards against

markets that are concentrated both in the home and the host country and on markets that are characterized by high entry barriers. Mergers occuring in such markets are particularly questionable from the competition policy point of view."

88. Johnson, An Economic Theory of Protectionism, Tariff Bargaining, and the Formation of Customs Unions, 73 J. POL. ECON. 256 (1965). 
monopoly. This attitude stems partly from differences in internal views on the value of market competition, but even more from the asymmetries in economic structure which lead to fears of dependence and domination. 